\title{
The Impact of Non-Financial Stakeholders on Accounting Conservatism: The Case of Labor Unions*
}

\author{
HSIN-YI (SHIRLEY) HSIEH ${ }^{* * *}$ \\ Tennessee State University \\ Nashville, TN, U.S.A. \\ BOOCHUN JUNG ${ }^{* * *}$ \\ University of Hawaii at Manoa \\ Honolulu, HI, U.S.A. \\ HAN YI ${ }^{* * * *}$ \\ Korea University Business School \\ Seoul, Korea
}

\begin{abstract}
This study examines the relation between labor union strength and conditional accounting conservatism. We argue that labor unions can have an increasing or decreasing effect on conditional conservatism due to considerations associated with layoffs and job security of union members. Using Basu's (1997) asymmetric timeliness framework and multiple measures of union strength, we find that labor union strength leads to less conditional conservatism, even after controlling for known determinants

* We thank Sudipta Basu, Xia Chen, Qiang Cheng, Mozaffar Khan, Bob Lipe, Mikhail Pevzner, Partha Sengupta, Ken Shaw, Wayne Thomas, Terry Warfield, workshop participants at Texas Christian University, the University of Hawaii, the University of Missouri, the University of Oklahoma, the University of Wisconsin, and participants at the 2009 Conference on Corporate Governance and Fraud Prevention at George Mason University and the 2009 AAA Annual Meeting for their helpful comments and suggestions. We especially thank David Farber for his inputs on earlier versions of this paper. All remaining errors are our own.

** First author, Assistant Professor, 3500 John A. Merritt Boulevard, Nashville, TN 37209, U.S.A.

*** Professor, 2404 Maile Way, Honolulu, HI 96822, U.S.A.

**** Corresponding author, Main Business Building 402, Korea University Business School, Seoul, Korea, e-mail: hanyi@korea.ac.kr
\end{abstract}


of conditional conservatism. Our results are robust to endogeneity tests as well as a battery of other sensitivity tests. We further demonstrate that the negative relation likely results from unions' ability to reduce the likelihood of layoffs. Overall, we provide fresh evidence about the impact of a key nonfinancial stakeholder, namely labor unions, on an important property of earnings.

Keywords: Accounting Conservatism, Conditional Conservatism, Labor Unions, Layoff

\section{INTRODUCTION}

We examine the relation between conditional accounting conservatism $^{1)}$ and labor union strength. ${ }^{2)}$ A strand of positive accounting research argues that managers have incentives to bias earnings downward to gain a bargaining advantage against unions (e.g., Liberty and Zimmerman 1986) with an implicit assumption that unions do not completely see through this downward earnings management. However, findings from this line of research are somewhat mixed. Moreover, this research focuses on unconditional conservatism, which is unlikely to result in efficient contracting (Ball and Shivakumar, 2005) and can be undone by labor unions to some extent. In addition, unconditional conservatism is less likely to be affected by managerial discretion than by accounting rules that require mandatory conservatism (Lawrence, Sloan, and Sun 2013). We extend the literature by examining the impact of labor union strength on conditional conservatism.

The literature (e.g., Chen, Kacperczyk, and Ortiz-Molina 2011) suggests that stronger labor unions significantly reduce firms' operating flexibility (e.g., wage reduction, layoffs, flexible staffing, etc). Stronger unions better negotiate with management to keep plants open and thus reduce the likelihood of employee layoffs

1) We refer to 'conditional accounting conservatism' simply as 'conservatism' for the remainder of the paper, unless otherwise specified.

2) Although the proportion of unionized private sector workers in the U.S. has declined from $17 \%$ in the 1980 s to $12 \%$ in the early part of this century (Flanagan 2005), unions remain an important factor in the U.S. (Hirsch 2004). Moreover, unionized workers comprise a significant proportion of private sector workers throughout the world, as follows: $24 \%$ in Japan, $32 \%$ in Canada, 35\% in the United Kingdom, 50\% in Australia, and over 60\% in Continental Europe and Scandinavia (Visser 2006). 
when they are no longer profitable (Pinnuck and Lillis 2007). ${ }^{3)}$ Consequently, the write-downs and restructuring charges that management might eventually take are not timely. If those writedowns and restructurings are not timely, then we observe less conditional conservatism for stronger labor unions, resulting in the negative relation between labor unions and their demand for conditional conservatism. On the other hand, the literature (e.g., Faleye, Mehrotra, and Morck 2006) suggests that unions can be thought as fixed claimants because, in many aspects, union workers' contractual wages and benefits mimic the payoff of risky debt holders. Therefore, similar to debt holders, unions may have a greater demand for conditional conservatism which would provide more downside information and prevent managers from engaging in excessively-risky future investments. In this case, conditional conservatism could increase with union strength.

In the presence of labor unions, managers seem to be willing to supply additional conditional conservatism since it may improve employers' bargaining position against labor unions. If unions' demand for conditional conservatism is positive, conditional conservatism would increase with union strength. In contrast, when unions object to terminations of unprofitable investments that involve layoffs of employees, they can enforce their objection and thus restrain the ability of managers to supply conditional conservatism through the threat of strikes. In this scenario, it is also plausible that managers would cater to unions if they prefer a 'quiet life' without the hassles of fighting with unions (Bertrand and Mullainathan 2003; Giroud and Mueller 2011). Thus, the relation between conditional conservatism and the strength of labor unions is an open empirical question.

To examine the effect of unions on conditional conservatism, we use the union strength measure, UNION, based on Hilary (2006). UNION is calculated as the product of the industry-level unionization rate from the Union Membership Coverage Database and firm-level labor intensity, which is the number of employees deflated by total assets. Although this measure is intended to capture firm-level union strength for a large sample of firms, we acknowledge that

3) Pinnuck and Lillis (2007) examine the relation between accounting losses and investment in employees and show that when firms report losses in the current year from profits in the last year, they significantly reduce investment in labor. Our results are consistent with Pinnuck and Lillis (2007). 
it contains noise. ${ }^{4)}$ We adopt Basu's (1997) asymmetric timeliness measure of conservatism to execute our main tests. Using a large sample over the years 1983-2006, we provide evidence that conditional conservatism decreases in the presence of stronger unions. Importantly, our results obtain even after controlling for bid-ask spread, the book-to-market ratio, size, leverage, and litigation risk. We also show that our main results are economically significant.

To support our argument underlying the negative relation between union strength and conditional conservatism, we perform an additional test and find that the probability of massive layoffs of employees indeed decreases in the strength of labor unions. This finding is consistent with the idea that the observed decreasing effect of labor unions on conditional conservatism likely stems from unions' ability to restrict the possibility to threaten the jobs of union members.

We perform additional tests to control for potential endogeneity. In a test for reverse causality, we assess whether conservatism increases following the exogenous shock of the passage of right-towork (RTW) laws. Because RTW laws can weaken union strength, we expect to observe less conditional conservatism prior to the passage of RTW laws. We report results consistent with our expectation. We also employ a two-stage least squares analysis to assess the possibility that correlated omitted variables drive our results. Inferences are unaffected by this test. Finally, we conduct a host of additional tests, including using alternative union strength measures, such as labor strike and defined benefit plans, and alternative measurement horizons, and controlling for CEO ownership, unconditional conservatism, and spurious regression bias due to the increasing time trend in conditional conservatism reported in the prior literature (e.g., Basu 1997; Holthausen and Watts 2001). Inferences are unaffected by these additional tests.

Our study extends research on the determinants of conditional conservatism. It complements studies that have documented increased demand for conditional conservatism due to higher agency costs associated with debt (Zhang 2008), lower managerial

4) We discuss this issue in more detail on pages 11-12. We also employ several other measures of labor union strength and show that our results are robust in Section 'Sensitivity Tests and Discussion'). 
ownership (LaFond and Roychowdhury 2008), and deadweight costs associated with asymmetric information across informed and uninformed traders (LaFond and Watts 2008). Our study underscores that a key non-financial stakeholder, namely unionized workforce, also impacts conditional conservatism. In a related study, Leung, Li, and Rui (2009) also examine the relation between labor unions and conservatism and find that conservatism increases after firms become unionized. Although this result seems contrary to ours, there are several important differences between our studies that can account for this outcome. We discuss these differences in Section 'Sensitivity Tests and Discussion'. More importantly, unlike Leung, Li, and Rui (2009), our study directly shows one possible economic mechanism - the likelihood of layoffs - which affects the negative relation between conditional conservatism and labor unions.

\section{LITERATURE REVIEW AND HYPOTHESIS}

\section{Conditional Accounting Conservatism}

A fundamental driver of accounting conservatism is the need for verifiable information that can be used to monitor managers who can take actions that benefit themselves or shareholders at the expense of other stakeholders (Watts 2003a, 2003b) such as investing in negative NPV projects or empire building. Conditional conservatism has been proposed as one of solutions to this problem. Basu (1997) characterizes conditional conservatism as requiring stricter verification standards for good news than for bad news. In other words, conditional conservatism involves the asymmetric timeliness in the recognition of economic gains versus economic losses. Ball (2001) argues that ex ante knowledge about this asymmetric timeliness will reduce management's incentive to invest in negative NPV projects or to engage in other activities that enhance managers' wealth at stakeholders' expense (e.g., excessive risktaking). Thus, conditional conservatism is hypothesized to reduce agency costs.

One stream of the conservatism literature has addressed the role of conservatism in resolving agency costs of debt. ${ }^{5}$ Beatty, Weber,

5) In addition to the studies that examine conditional conservatism, Ahmed, 
and $\mathrm{Yu}$ (2008) show that the ability of debt holders to include contract modifications does not necessarily preclude the demand for conservative report. Both Zhang (2008) and Wittenberg-Moerman (2008) report a negative relation between the level of conditional conservatism and cost of debt, in terms of initial borrowing cost and bid-ask spreads in the secondary loan trade, respectively. Ball, Robin, and Sadka (2008) use a cross-country setting and find that debt markets drive the demand for conservatism. Ball, Bushman, and Vasvari (2008) find that information asymmetry between the lead underwriter and other syndicate participants is negatively related to the inherent ability of firms' accounting information to capture credit quality deterioration on a timely basis.

Researchers have also assessed the role of conditional conservatism in reducing agency conflicts between managers and shareholders. Ahmed and Duellman (2007) show that firms with more outside directors on their boards exhibit more conservatism. LaFond and Watts (2008) report that conditional conservatism reduces information asymmetry between uninformed and informed traders, thereby increasing firm value. LaFond and Roychowdhury (2008) report a negative relation between managerial ownership and conditional conservatism, implying that the demand for conditional conservatism is greater for firms with more severe agency problems between management and shareholders. Francis and Martin (2009) find a positive relation between conservatism and both announcement returns for acquisitions as well as acquisition profitability. In sum, extant research supports the notion that conditional conservatism is useful for reducing information asymmetry, resulting in more efficient contracting.

\section{The Impact of Labor Unions on Accounting Conservatism}

It is well-known that stronger unions significantly reduce firms' operating flexibility (Chen, Kacperczyk, and Ortiz-Molina 2011). For example, stronger labor unions better negotiate with management to keep plants open even when they are not profitable and need

Billings, Morton, and Harris-Stanford (2002) document a positive relation between measures of unconditional conservatism and the degree of agency problems between bondholders and shareholders, suggesting that firms with more severe conflicts between bondholders and shareholders adopt more conservative accounting. 
to be discontinued, resulting in the lower likelihood of employee layoffs. ${ }^{6}$ In addition, collective bargaining agreements often include restrictions on firms' ability to lay off employees (Chen, Kacperczyk, and Ortiz-Molina 2011). Abraham and Medoff (1984) provide evidence that layoff protection for senior workers is stronger at unionized firms than at non-unionized firms. As a result, the writedowns and restructuring charges which should be accounted for eventually are more likely to be less timely, leading to less conditional conservatism for stronger labor unions.

In addition, accounting information in collective bargaining influences the perception of the employers' 'ability to pay' wages and benefits demanded by the employees (Foley and Maunders 1977; Palmer 1977; Craft 1981). Timely recognition of losses but not gains can lower the firm's perceived ability to pay and adversely affect the bargaining position of labor unions against management. Thus, conditional conservatism can be costly to union members, suggesting the negative relation between labor unions and their demand for conditional conservatism.

However, the effect of labor unions on less conditional conservatism may be mitigated by unions' concerns on long-run job security. Faleye, Mehrotra, and Morck (2006) argue that because unionized workers' contractual wages and benefits are similar to the payoff on risky debt, ${ }^{7)}$ unions likely have some economic preferences that are similar to those of fixed claimants, e.g., sharing only downside risk, but limited upside benefit. ${ }^{8}$ Accordingly, to protect their workers'

6) We formally test this argument in Subsection 'Unions and the Likelihood of Layoff' and find that the likelihood of layoffs is negatively related to union strength.

7) Because at least part of unionized workers' pensions are guaranteed through the Pension Benefit Guaranty Board, unionized workers also share characteristics of bondholders with secured debt.

8) Although we argue that unions share characteristics of fixed claimants, because unionized workers also share their firm's profitable investments through employee ownership, increased wages and benefits, and increased employment, it is possible that union members and leaders behave like residual claimants. While we acknowledge that unionized workers have characteristics of both residual claimants and fixed claimants, we believe that it is reasonable to assume that because unionized workers' fixed claims represent a more substantial component of their total claims on firm value, unions' role as a fixed claimant would likely dominate their role as a residual claimant. Furthermore, Hirsch (1991) argues that unions behaving as residual claimants is an unlikely equilibrium because the average union member is typically 'rationally myopic' in that they ignore the welfare of future members and tend to discount long-term outcomes. Union 
long-term economic welfare, unions may have incentives to use their bargaining power to demand more downside information from firms, which can be achieved through increased conditional conservatism. ${ }^{9)}$

In sum, the net effect of labor unions on accounting conservatism can be positive or negative, depending on whether the perceived benefit, in terms of overall job viability, outweighs the potential cost in the form of job cuts in the short-run.

\section{The Supply of Accounting Conservatism}

As discussed earlier, accounting information affects the perception of firms' ability to pay, which, may create incentives for managers to downplay the performance of the company through their discretion on reporting and disclosure choices. Prior research uses labor unions as a powerful setting for understanding accounting choices because unions are more (less) likely to demand increased wages and benefits when earnings are better (worse). This stream of research is motivated by the idea that managers have incentives to bias earnings downward prior to union contract negotiations in order to reduce unions' demand for increased wages and benefits. However, Liberty and Zimmerman (1986) document no evidence of temporary earnings decreases during labor contract negotiations for 105 U.S. firms over the period 1968-1981. ${ }^{10)}$ Cullinan and Knoblett (1994) report no relation between unionization and either inventory or depreciation choices. In contrast, DeAngelo and DeAngelo (1991) report lower net income during negotiation periods with unions compared to non-negotiation periods. This result may not be generalizable, however, because it is based on only seven U.S. steel firms. D'Souza, Jacob, and Ramesh (2001) find that more

myopia is further exacerbated by the horizon issue of union leaders, who are typically senior members with fewer years of service left than average union members (Hirsch 1991).

9) Although we propose two opposing views on the relation between unions and conservatism, instead of unions demanding, and getting a particular accounting treatment (less or more conditional conservatism), it is more likely that unions successfully negotiate particular operational characteristics (keeping plants open), thereby indirectly affecting conditional conservatism. We do not claim that labor union leaders would directly and explicitly ask management to use (more or less) conditional conservatism.

10) Yamaji (1986) and Mautz and Richardson (1992) find results similar to those in Liberty and Zimmerman (1986). 
unionized firms tend to use immediate recognition under SFAS 106 to reduce current net income. Bova (2013) shows that unionized firms are more likely to miss earnings forecasts due to expectations management, rather than earnings management, to signal a negative outlook to their unions. ${ }^{11)}$

The literature reviewed above focuses on unconditional accounting conservatism, whereas this paper concentrates on conditional conservatism for several reasons. First, unconditional conservatism is unlikely to improve contracting efficiency as parties involved can contract around it (Ball and Shivakumar 2005). Second, unconditional conservatism alone is unlikely to suffice in bringing down the perception of unions as its effect can be identified and accounted for to some extent. For example, union negotiators often use earnings numbers with depreciation expense added back (Foley and Maunders 1977). Finally, unconditional conservatism is less likely to be affected by managerial discretion than by accounting rules that require mandatory conservatism (Lawrence, Sloan, and Sun 2013).

Managers can also attain the objective of tainting the perceived ability to pay by consistently accelerating the recognition of bad news or, stated differently, by supplying more conditional conservatism. Additionally, labor negotiations are not limited to major negotiations that occur every few year (Katz 1993; Frost 2000), and even the major negotiations can take place over a long period of time. The recurring nature and the long duration of negotiations with labor unions can further intensify managers' incentives to maintain a conservative reporting policy.

However, managers' ability to supply conditional conservatism can be limited by the presence of strong unions. If the termination of poor existing investments entails massive layoffs of employees,

11) Another set of papers examines how other stakeholders create incentives for managers to adopt less conservative financial reporting in order to improve managerial reputation, which enhances job security and relieves labor's concerns about firm performance. For example, Bowen, DuCharme, and Shores (1995) investigate managers' incentives to choose income-increasing accounting methods for inventory and depreciation. They show that a firm's implicit claims with its stakeholders, such as customers, suppliers, and short-term creditors, influence managers' accounting choices in ways that increase long-run income, although they provide inconclusive evidence for implicit claims with employees. Cornell and Shapiro (1987) and Maksimovic and Titman (1991) also suggest that a firm's financial image is important for stakeholders because it allows them to assess the firm's fulfillment of implicit commitments. 
managers will likely face strong oppositions from the unionized labor force. For example, Antanassov and Kim (2009) find that the likelihood of layoffs decreases in the strength of legal protection of labor. Furthermore, the timelier the decision for termination is made, the greater the hurdle management will likely face in convincing unions that the timelier (or earlier) termination is necessary in the absence of a long history of losses. In this situation, managers can possibly cater to unions' oppositions, due to their preference for a 'quiet life' (Bertrand and Mullainathan 2003) and aversion to the hassles of fighting with labor unions (Giroud and Mueller 2011).

Based on the discussion above, the relation between union strength and conditional conservatism is an open empirical question. This leads to our hypothesis, stated in the null form:

Hypothesis: There is no relation between labor union strength and conditional conservatism.

\section{SAMPLE AND UNION STRENGTH MEASURE}

Our initial sample consists of firms for which industry unionization data exist and for which financial information and return data are available from Compustat and CRSP. We eliminate firms in the utility (SIC code between 49 and 50) and financial industries (SIC code between 60 and 68) because of their unique financial reporting requirements. We obtain our unionization data from the Union Membership and Coverage Database (www. unionstats.com) that Hirsch and Macpherson constructed (see Hirsch and Macpherson 2003). This database has been used in the accounting (e.g., Hilary 2006) and finance (e.g., Chen, Kacperczyk, and Ortiz-Molina 2011, 2012; Klasa, Maxwell, and Ortiz-Molina 2009) literatures and provides estimates of union membership and coverage data by industry that are derived from the Current Population Survey-Outgoing Rotation Group's (CPS-ORG) monthly earnings files. The Current Population Survey (CPS) is a monthly survey of rotated groups of households conducted by the Bureau of Census for the Bureau of Labor Statistics (BLS) to collect information about labor force characteristics of the U.S. population. Information on union membership status is included in the survey starting in 1983. 
Using the BLS methodology, Hirsch and Macpherson (2003) provide estimates of union membership and coverage information by metropolitan area, industry, and occupation; they update the database annually when survey results become available. CPS uses the Census Industry Classification (CIC) code as the industry indicator. Prior to 2003, CIC corresponds to the Standard Industrial Classification (SIC) code, and to the North American Industry Classification System (NAICS) thereafter.

To link the labor union data to firms in Compustat, we first create a mapping of the CIC code to a SIC or NAICS code of all Compustat firms for each year. For the majority of unique SIC or NAICS codes, we identify an exact corresponding CIC code using technical documents from the CPS database and from the U.S. Census Bureau's website. ${ }^{12)}$ For the SIC/NAICS codes for which exact mapping cannot be found, we assign corresponding CIC code(s) based on the industry name. When the industry name of SIC/NAICS codes in Compustat covers multiple industries under the CIC, we assign multiple CIC codes. This means that the unionization measure for these affected firms is a simple average of all census industries in which these firms operate. ${ }^{13)}$ Finally, we exclude firms with SIC codes of 9000-9999 and NAICS codes of 900000-999999 because they are not referenced in either the CPS database or the U.S. Census Bureau website. ${ }^{14)}$

The main variable from the Hirsch and Macpherson (2003) dataset is the percentage of workers with explicit union membership in a given industry. Following Hilary (2006), we convert the industry-level data to firm-level data by multiplying the industry-level unionization measure by the number of employees in each firm scaled by lagged total assets (hereafter UNION). ${ }^{15)}$ We acknowledge that this adjustment results in a firm-level unionization measure that is noisy because it ignores the dynamics of the relationship between labor and deployed capital. On one hand, if labor and capital are

12) U.S. Census Bureau: http://www.census.gov/

13) As a sensitivity test, we also use weighted average and inferences are unaffected. See Subsection 'Alternative Measures of Labor Union Strength' for details.

14) These industries include conglomerates, non-operating establishments, and real estate investment trusts.

15) We also test our hypothesis using industry-level estimates for union strength and conservatism and find similar results to those reported. We discuss these results in Section 'Sensitivity Tests and Discussion'. 
Table 1. Most and least unionized industries by Census Industry Classification (CIC)

\begin{tabular}{|c|c|c|c|c|c|c|}
\hline \multirow[b]{2}{*}{ Rank } & \multicolumn{3}{|c|}{ Ten Most Unionized Industries } & \multicolumn{3}{|c|}{ Ten Least Unionized Industries } \\
\hline & $\begin{array}{c}\text { CIC } \\
\text { Code }\end{array}$ & Industry Name & $\begin{array}{l}\text { Percentage } \\
\text { of Labor } \\
\text { with Union } \\
\text { Membership }\end{array}$ & $\begin{array}{l}\text { CIC } \\
\text { Code }\end{array}$ & Industry Name & $\begin{array}{l}\text { Percentage } \\
\text { of Labor } \\
\text { with Union } \\
\text { Membership }\end{array}$ \\
\hline 1 & 400 & Railroads & 72.59 & 590 & $\begin{array}{l}\text { Mobile home } \\
\text { dealers }\end{array}$ & 0.00 \\
\hline 2 & 270 & $\begin{array}{l}\text { Blast furnaces, } \\
\text { steelworks, rolling } \\
\text { and finishing mills }\end{array}$ & 47.29 & 801 & $\begin{array}{l}\text { Video tape } \\
\text { rental }\end{array}$ & 0.46 \\
\hline 3 & 160 & $\begin{array}{l}\text { Pulp, paper, and } \\
\text { paperboard mills }\end{array}$ & 45.07 & 890 & $\begin{array}{l}\text { Accounting, } \\
\text { auditing, and } \\
\text { bookkeeping } \\
\text { services }\end{array}$ & 0.96 \\
\hline 4 & 421 & Air transportation & 40.27 & 732 & $\begin{array}{l}\text { Computer and } \\
\text { data processing } \\
\text { services }\end{array}$ & 1.08 \\
\hline 5 & 272 & $\begin{array}{l}\text { Primary } \\
\text { aluminum } \\
\text { industries }\end{array}$ & 38.50 & 660 & Jewelry stores & 1.13 \\
\hline 6 & 401 & $\begin{array}{l}\text { Bus service and } \\
\text { urban transit }\end{array}$ & 38.31 & 11 & $\begin{array}{l}\text { Agricultural } \\
\text { production, } \\
\text { livestock }\end{array}$ & 1.16 \\
\hline 7 & 351 & $\begin{array}{l}\text { Motor vehicles } \\
\text { and motor vehicle } \\
\text { equipment }\end{array}$ & 36.74 & 640 & $\begin{array}{l}\text { Household } \\
\text { appliances, TV, } \\
\text { and radio stores }\end{array}$ & 1.30 \\
\hline 8 & 271 & $\begin{array}{l}\text { Iron and steel } \\
\text { foundries }\end{array}$ & 35.54 & 633 & $\begin{array}{l}\text { Radio, TV, and } \\
\text { computer stores }\end{array}$ & 1.38 \\
\hline 9 & 361 & $\begin{array}{l}\text { Railroad } \\
\text { locomotives and } \\
\text { equipment }\end{array}$ & 35.52 & 20 & $\begin{array}{l}\text { Agricultural } \\
\text { services, } \\
\text { excluding } \\
\text { horticultural }\end{array}$ & 1.52 \\
\hline 10 & 250 & $\begin{array}{l}\text { Glass and glass } \\
\text { products }\end{array}$ & 34.09 & 740 & $\begin{array}{l}\text { Computer and } \\
\text { data processing } \\
\text { services }\end{array}$ & 1.70 \\
\hline
\end{tabular}

This table presents the ten most highly unionized industries as well as the ten least unionized industries based on pooled industry-level union membership data over the period 1983-2006. 
independent, then UNION more readily captures relative labor power. On the other hand, if labor and capital are interdependent and a small labor force can operate a large amount of capital, then UNION does not seem to capture union strength. In light of the noise in our firm-level unionization measure, we employ several additional union strength measures and explain the results based on those alternative measures in Section 'Sensitivity Tests and Discussions'. We merge the union dataset with Compustat and CRSP to create a final sample of 65,082 firm-year observations for the period 1983-2006. ${ }^{16)}$ Table 1 shows the ten most and least unionized industries. We report that the most unionized workforce is in the transportation and manufacturing industries such as railroads, steel manufacturing, pulp and paper, motor vehicles, and glass products, while the least unionized workforce is in service and retail industries such as mobile home dealers, video tape rental, accounting services, and jewelry stores. These statistics are generally similar to those in prior studies (e.g., Chen, Kacperczyk, and Ortiz-Molina 2012; Klasa, Maxwell, and Ortiz-Molina 2009).

\section{RESEARCH DESIGN AND RESULTS}

\section{Research design}

We use Basu's (1997) measure of conditional conservatism to execute our tests. Basu (1997) estimates the following model, predicting and finding a significant and positive $\mathrm{a}_{3}$.

$$
N I=\alpha_{0}+\alpha_{1} N E G+\alpha_{2} R E T+\alpha_{3} R E T^{*} N E G+\varepsilon
$$

where (for brevity, we omit firm and year index $i$ and $t$, respectively) $N I$ is net income of firm $i$ in year $t$, deflated by market value of equity at the beginning of year $t, R E T$ is the CRSP twelve month buy-andhold return of firm $i$ ending in the month of its fiscal year-end $t{ }^{17)}$ and $N E G$ is a dummy variable coded as 1 if RET is less than zero, 0 otherwise.

16) Because of data constraints, sample size varies across analyses.

17) Inferences are unchanged when RET is the CRSP twelve-month buy-and-hold return of firm $i$ ending in the third month after the fiscal year-end (untabulated). 
A positive and significant $\mathrm{a}_{3}$ means that bad news (NEG) is more quickly reflected in financial reporting (NI) than good news, consistent with managers imposing stricter verification requirements for gains than for losses when reporting earnings. The magnitude of the positive coefficient on $a_{3}$ has been widely used to document the degree of conditional (i.e., news-dependent) conservatism in financial reporting (Ball, Kothari, and Nikolaev 2013). In the spirit of prior research (e.g., LaFond and Roychowdhury 2008), we estimate the following specification based on the Basu (1997) model:

$$
\begin{aligned}
& N I=\beta_{0}+\beta_{1} N E G+\beta_{2} U N I O N+\beta_{3} B M+\beta_{4} L E V+\beta_{5} S I Z E+\beta_{6} L I T \\
& +\beta_{7} B I D A S K+\beta_{8} N E G * U N I O N+\beta_{9} N E G * B M \\
& +\beta_{10} N E G * L E V+\beta_{11} N E G * S I Z E+\beta_{12} N E G * L I T \\
& +\beta_{13} N E G * B I D A S K+\beta_{14} R E T+\beta_{15} R E T * U N I O N \\
& +\beta_{16} R E T * B M+\beta_{17} R E T * L E V+\beta_{18} R E T * S I Z E \\
& +\beta_{19} R E T * L I T+\beta_{20} N E G * B I D A S K+\beta_{21} R E T * N E G \\
& +\beta_{22} R E T * N E G * U N I O N+\beta_{23} R E T * N E G * B M \\
& +\beta_{24} R E T \text { * NEG * } L E V+\beta_{25} R E T \text { * NEG * SIZE } \\
& +\beta_{26} R E T * N E G * L I T+\beta_{27} R E T * N E G * B I D A S K+\varepsilon
\end{aligned}
$$

where NI, NEG, and RET are defined in model (1). UNION represents labor union strength as described previously.

Our empirical model also includes control variables known to be related to conservatism. $B M$ is the book-to-market ratio, which reflects growth options. Watts (2003a) argues that firms with high growth options (i.e., a high market-to-book ratio) tend to have higher contracting costs. Consistent with this notion, Roychowdhury and Watts (2007) and Hui, Klasa, and Yeung (2012) show a positive association between the market-to-book ratio and conditional conservatism. Because we use the inverse of market-to-book, we expect a negative association between $B M$ and conditional conservatism. We measure $B M$ as book value of equity divided by market value of equity at the year end. $L E V$ is the leverage ratio and reflects lenders' demand for conservatism. The greater the firm's leverage, the greater is the information asymmetry between shareholders and lenders, leading lenders to demand more conservatism. We measure $L E V$ as the sum of long-term debt and current liabilities, scaled by beginning-of-year total assets. We also include firm size (SIZE), which is measured as the market value of 
equity. Prior research shows that larger firms are less conditionally conservative (LaFond and Watts 2008; LaFond and Roychowdhury 2008). The literature suggests that litigation risk is also related to conservatism (Watts 1993). Following Kim and Skinner (2012), we include a measure of litigation risk, LIT, an indicator variable equal to 1 if firm $i$ is in a litigious industry (biotech, computer, electronics, and retail firms - SIC codes 2833-2838 and 8731-8734; 3570-3577 and 7370-7374; 3600-3674; 5200-5961) in year $t$, 0 otherwise.

Hilary (2006) reports that information asymmetry increases with union strength, suggesting that firms are less likely to disclose information that unions can use to their bargaining advantage. Given that conservatism also increases with information asymmetry (LaFond and Watts 2008), our model would have an omitted variables problem if it did not include bid-ask spread (BIDASK) as an additional proxy for information asymmetry. ${ }^{18)}$ We measure $B I D A S K$ as the average of the monthly median values of the absolute value of the difference between the closing bid price and the closing ask price from the CRSP daily file, deflated by the closing price.

\section{Descriptive Statistics and Correlations}

Panel A of Table 2 presents descriptive statistics for the variables used in the main regression analysis. UNION appears to have a good level of variation, ranging from $1 \%(\mathrm{Q} 1)$ to $13 \%(\mathrm{Q} 3)$, with a mean of $11 \%$. The mean (median) net income deflated by beginning of year market value of equity $(N I)$ is $-0.02(0.04)$. Sample firms generate $11 \%$ returns on average $(R E T)$ and the mean of the negative return indicator variable $(N E G)$ is $0.48 .{ }^{19)}$ Sample firms also have a mean book-to-market ratio $(B M)$ of 0.66 and a mean market value of equity (SIZE) of $\$ 967.99$ million. The mean leverage ratio $(L E V)$ is 0.24 . The mean litigation ( $L I T)$ value of 0.37 indicates that a little more than one-third of our sample firms operate in a litigious environment.

Panel B of Table 2 reports Pearson coefficients of correlation between the variables used in the main regression analyses. The

18) There are several proxies for information asymmetry, such as PIN (probability of informed trading), bid-ask spread, and trading volume (Hilary 2006; LaFond and Watts 2008). We don't use PIN because it would severely restrict our sample size. In untabulated tests, we used trading volume, leaving inferences unaffected.

19) The mean value of NEG for the universe of Compustat/CRSP over the years $1983-2006$ is 0.58 . 
Table 2. Descriptive statistics and correlations

Panel A: Summary statistics for variables used in the main regressions

\begin{tabular}{l|c|c|c|c|c|c}
\hline \hline Variable & $\mathrm{N}$ & Mean & Std. Dev. & 25th & Median & 75th \\
\hline NI & 65,082 & -0.02 & 0.21 & -0.05 & 0.04 & 0.08 \\
RET & 65,082 & 0.11 & 0.57 & -0.28 & 0.03 & 0.38 \\
$N E G$ & 65,082 & 0.48 & 0.50 & 0.00 & 0.00 & 1.00 \\
$B M$ & 65,082 & 0.66 & 0.57 & 0.29 & 0.50 & 0.84 \\
LEV & 65,082 & 0.24 & 0.25 & 0.03 & 0.18 & 0.37 \\
SIZE & 65,082 & 967.99 & 3065.80 & 29.37 & 103.43 & 457.84 \\
UNION & 65,082 & 0.11 & 0.17 & 0.01 & 0.05 & 0.13 \\
LIT & 65,082 & 0.37 & 0.48 & 0.00 & 0.00 & 1.00 \\
BIDASK & 65,082 & $4.72 \%$ & $6.24 \%$ & $1.09 \%$ & $2.59 \%$ & $5.69 \%$ \\
\hline
\end{tabular}

correlation coefficients show that net income, $N I$ is positively (negatively) correlated with RET, LEV, and SIZE (NEG, BM, LIT, and $B I D A S K)$. Although these correlations are consistent with prior research (e.g., LaFond and Roychowdhury 2008), one might expect a negative correlation between $N I$ and $L E V$ due to interest expense (Modigliani and Miller, 1958). Panel B also shows that firms with higher levels of unionization (UNION) have higher net income (NI), higher returns $(R E T)$ and a lower incidence of negative returns $(N E G)$. These firms also have lower growth opportunities $(B M)$, are smaller (SIZE), have a higher leverage ratio ( $L E V)$, and operate in a less litigious environment (LIT). The correlation between UNION and BIDASK is positive and significant, consistent with the result in Hilary (2006).

\section{Main Empirical Results}

We report results for our tests of Hypothesis in Table 3. Similar to prior research (e.g., LaFond and Roychowdhury 2008; Verdi 2006), we use decile ranks of UNION, BM, SIZE, LEV, and BIDASK in the regression analyses to minimize the influence of outliers on the explanatory and control variables and to facilitate an assessment of the economic significance of results for these variables. ${ }^{20)}$ Since the regression residuals could be correlated over time and/or across firms in the pooled OLS regressions, we follow Petersen (2009) and

20) Our main results are robust to using continuous measures of our variables instead of decile rank measures. 
Table 2. (continued)

Panel B: Pearson Correlation Coefficients

\begin{tabular}{|c|c|c|c|c|c|c|c|c|c|}
\hline & $N I$ & $R E T$ & $N E G$ & $B M$ & $L E V$ & $S I Z E$ & UNION & $L I T$ & BIDASK \\
\hline \multirow[t]{2}{*}{$N I$} & \multirow[t]{4}{*}{1} & 0.239 & -0.239 & -0.176 & 0.012 & 0.080 & 0.117 & -0.103 & -0.303 \\
\hline & & $<.0001$ & $<.0001$ & $<.0001$ & 0.002 & $<.0001$ & $<.0001$ & $<.0001$ & $<.0001$ \\
\hline \multirow[t]{2}{*}{$R E T$} & & 1 & -0.747 & -0.345 & 0.005 & -0.011 & 0.054 & -0.009 & -0.329 \\
\hline & & & $<.0001$ & $<.0001$ & 0.203 & 0.007 & $<.0001$ & 0.018 & $<.0001$ \\
\hline \multirow[t]{2}{*}{$N E G$} & & & 1 & 0.291 & -0.002 & -0.046 & -0.053 & 0.051 & 0.300 \\
\hline & & & & $<.0001$ & 0.565 & $<.0001$ & $<.0001$ & $<.0001$ & $<.0001$ \\
\hline \multirow[t]{2}{*}{$B M$} & & & & 1 & 0.024 & -0.158 & 0.010 & -0.103 & 0.414 \\
\hline & & & & & $<.0001$ & $<.0001$ & 0.008 & $<.0001$ & $<.0001$ \\
\hline \multirow[t]{2}{*}{$L E V$} & & & & & 1 & 0.004 & 0.178 & -0.204 & 0.047 \\
\hline & & & & & & 0.281 & $<.0001$ & $<.0001$ & $<.0001$ \\
\hline \multirow[t]{2}{*}{$S I Z E$} & & & & & & 1 & -0.082 & 0.019 & -0.189 \\
\hline & & & & & & & $<.0001$ & $<.0001$ & $<.0001$ \\
\hline \multirow[t]{2}{*}{ UNION } & & & & & & & 1 & -0.202 & 0.030 \\
\hline & & & & & & & & $<.0001$ & $<.0001$ \\
\hline$L I T$ & & & & & & & & 1 & -0.037 \\
\hline & & & & & & & & & $<.0001$ \\
\hline$B I D A S K$ & & & & & & & & & 1 \\
\hline
\end{tabular}

$N I$ : Net income of firm $i$ in year $t$ (Compustat \#172), deflated by the market value of equity at the beginning of year $t$ (Compustat \#25*\#199).

RET: CRSP buy-and-hold returns of firm $i$ in year $t$; we cumulate returns over the twelve months starting with the first month of the fiscal year.

$N E G$ : An indicator variable coded as 1 if RET is less than zero, 0 otherwise.

$B M$ : The book-to-market ratio of firm $i$ at the end of year $t$, calculated as book value of equity (Compustat \# 60) divided by the market value of equity (Compustat \#25* \#199).

$L E V$ : The leverage ratio defined as the sum of the long-term debt (Compustat \#9) and current liabilities (Compustat \#34), scaled by beginning of year total assets (Compustat \#6).

SIZE: The market value of equity of firm $i$ at the beginning of year $t$ (in \$million).

UNION: A measure of union membership based on the Current Population Survey. We define this variable as the product of (1) the percentage of respondents of the Current Population Survey that answer YES to the question on whether they are members of a union in a given industry and (2) the number of employees of firm $i$ in year $t$ (Compustat \#29) scaled by beginning of year total assets (Compustat \#6).

LIT: Following Kim and Skinner (2012), LIT is an indicator variable coded as 1 if firm $i$ is in a litigious industry (biotech, computer, electronics, and retail firms SIC codes 2833-2838 and 8731-8734; 3570-3577 and 7370-7374; 3600-3674; 5200-5961), and zero otherwise.

BIDASK: The average of the monthly median spread between the closing bid and closing ask from the CRSP daily stock file, scaled by closing price. 
Table 3. OLS regression of the effect of labor unions on conditional conservatism

\begin{tabular}{|c|c|c|c|}
\hline Variable & Coeff. & t-sta & \\
\hline Intercept & 0.047 & 7.05 & $* * *$ \\
\hline$N E G$ & -0.118 & -6.45 & $* * *$ \\
\hline UNION & 0.048 & 5.10 & $* * *$ \\
\hline$B M$ & -0.043 & -2.97 & $* * *$ \\
\hline$L E V$ & 0.011 & 0.92 & \\
\hline SIZE & 0.000 & 0.28 & \\
\hline$L I T$ & -0.027 & -4.37 & $* * *$ \\
\hline$B I D A S K$ & -0.224 & -2.49 & $* *$ \\
\hline$N E G^{*} U N I O N$ & 0.036 & 4.08 & $* * *$ \\
\hline$N E G^{*} B M$ & 0.138 & 7.92 & $* * *$ \\
\hline$N E G^{*} L E V$ & -0.020 & -2.22 & $* *$ \\
\hline$N E G * S I Z E$ & 0.094 & 5.80 & $* * *$ \\
\hline$N E G^{*} L I T$ & 0.010 & 1.28 & \\
\hline$N E G^{*} B I D A S K$ & -0.029 & -1.56 & \\
\hline$R E T$ & -0.070 & -2.86 & $* * *$ \\
\hline$R E T^{*} U N I O N$ & 0.095 & 5.58 & $* * *$ \\
\hline$R E T^{*} B M$ & 0.220 & 9.82 & $* * *$ \\
\hline$R E T^{*} L E V$ & -0.019 & -1.89 & * \\
\hline$R E T^{*}$ SIZE & 0.066 & 2.59 & $* *$ \\
\hline$R E T^{*} L I T$ & -0.009 & -0.93 & \\
\hline$R E T * B I D A S K$ & -0.121 & -2.96 & $* * *$ \\
\hline$R E T^{*} N E G$ & 0.256 & 6.27 & $* * *$ \\
\hline$R E T^{*} N E G^{*} U N I O N$ & -0.136 & -4.21 & $* * *$ \\
\hline$R E T^{*} N E G^{*} B M$ & -0.130 & -4.86 & $* * *$ \\
\hline$R E T^{*} N E G^{*} L E V$ & 0.091 & 3.94 & $* * *$ \\
\hline$R E T^{*} N E G * S I Z E$ & -0.252 & -7.54 & $* * *$ \\
\hline$R E T^{*} N E G^{*} L I T$ & 0.018 & 0.86 & \\
\hline$R E T^{*} N E G^{*} B I D A S K$ & 0.140 & 3.26 & $* * *$ \\
\hline $\mathrm{N}$ & \multicolumn{3}{|c|}{65,082} \\
\hline Adjusted $\mathrm{R}^{2}$ & \multicolumn{3}{|c|}{$20.37 \%$} \\
\hline
\end{tabular}

This table presents results from OLS regression of Basu's (1997) asymmetric timeliness framework with robust standard errors by both firm and year clusters (Petersen, 2009). The dependent variable is NI, net income deflated by the market value of equity at the beginning of year t. RET is CRSP buy-and-hold returns over the twelve months beginning with the first month of the firm's fiscal year. $N E G$ is an indicator variable coded as 1 if $R E T$ is less than zero; 0 otherwise. For the interaction terms in this regression, we measure $B M, L E V$, SIZE, and BIDASK as rank-variables based on annual deciles (see Table 2 for variable definitions). LIT is a dummy coded as 1 for the litigious industries (and 0 otherwise) following Kim and Skinner (2012). UNION is defined as the product of (1) the percentage of respondents of the Current Population Survey that answer YES to the question of whether they are members of a union in a given industry and (2) the number of employees of firm $i$ in year $t$ (Compustat \#29) scaled by beginning of year total assets (Compustat \#6).

$* * *, * *, *$ indicate significance at the $0.01,0.05$, and 0.10 levels, respectively (two-sided). 
Thompson (2011), and report robust t-statistics adjusted for both firm and fiscal year clusters. ${ }^{21)}$

Conditional conservatism predicts a positive coefficient on $R E T^{*} N E G$, indicating that managers incorporate bad news into earnings on a more timely basis than good news. In Table 3, we report that the coefficient on $R E T^{*} N E G$ is 0.256 and significant ( $t=$ 6.27), confirming the predicted sign for this relation. ${ }^{22)}$ Our variable of interest is the interactions between $R E T^{*} N E G$ and UNION. We report that the coefficient on $R E T^{*} N E G^{*} U N I O N$ is -0.136 and significant $(t=-4.21)$, implying that the asymmetric recognition of economic losses versus economic gains is more pronounced for firms with lower levels of union strength. ${ }^{23)}$ The coefficient on $R E T^{*} N E G^{*} B M$ is significantly negative $(=-0.130)$, consistent with results in prior studies (e.g., Roychowdhury and Watts 2007; Hui, Klasa, and Yeung 2012). We also report a significant coefficient on $R E T^{*} N E G^{*} L E V$ of 0.091 , consistent with LaFond and Watts (2008). The coefficient on $R E T^{*} N E G * S I Z E$ is -0.252 , also consistent with past studies (e.g., Givoly, Hayn, and Natarajan 2007; Khan and Watts 2009). Finally, we show a positive but insignificant coefficient of 0.018 on $R E T^{*} N E G^{*} L I T$. The positive and significant coefficient on BIDASK is consistent with LaFond and Watts (2008).

Our results are also economically significant. The coefficient of -0.136 on $R E T^{*} N E G^{*} U N I O N$ is economically significant compared to other predictors of conditional conservatism. The magnitude of this coefficient is comparable to the coefficients on $R E T^{*} N E G * B M$ (= -0.130). While the coefficient on $R E T^{*} N E G^{*} U N I O N$ is smaller than the coefficients on $R E T^{*} N E G{ }^{*} \operatorname{SIZE}(=-0.252)$, it is nevertheless a substantial proportion of the coefficient on $R E T^{*} N E G$ (about onehalf). Additionally, when a firm moves from the highest UNION decile

21) Our results are also robust to panel data models and Fama-Macbeth (1973) regressions. Following Ball, Kothari, and Nikolaev's (2013) response to a criticism by Patatoukas and Thomas (2011) regarding the asymmetric timeliness measure, we also use a fixed effects model and find that inferences do not change.

22) The sign on RET is negative, but when we drop BIDASK and UNION from our model, the sign on RET is positive and significant, consistent with prior research.

23) Given the large number of variables and potential for multicollinearity, we assess the 'usefulness' (Darlington 1968) of UNION variable by performing an F-test to determine whether the collective contribution of the set of UNION-related variables (e.g., UNION, NEG*UNION, RET*UNION, and RET*NEG*UNION) is significant. The $\mathrm{F}(4,65054)$ value is 26.16 ( $\mathrm{p}$-value $=0.0000)$, indicating that there is a significant difference between the 'full' model with UNION (R-squared $=0.2037$ ) and the 'reduced' model without UNION (R-squared=0.1914). 
to the lowest UNION decile, conservatism roughly doubles (= from 0.120 (i.e., coefficient on $R E T^{*} N E G+$ coefficient on $R E G^{*} N E G^{*} U N I O N$ $=0.256-0.136$ ) to 0.256 (i.e., coefficient on $\left.R E T^{*} N E G\right)$ ). ${ }^{24)}$

Overall, results reported in Table 3 support the notion that conditional conservatism declines in union strength and that the effect of union strength on conditional conservatism cannot be attributed to other documented sources of conditional conservatism.

\section{Endogeneity Tests}

It is possible that endogeneity drives our results. Our arguments and results suggest that the direction of causality runs from union strength to conditional conservatism. However, it is possible that the causal relation is opposite to what we predict. To assess whether reverse causality affects our results, we employ a changes analysis based on an exogenous shock of changes in states' right-to-work laws. It is also possible that correlated omitted variables drive our results. To determine the impact of correlated omitted variables on our results, we estimate a two-stage least squares analysis.

\section{Changes in Right-to-Work Laws}

Prior studies often use changes in state laws as exogenous shocks to firm-level decision-making to draw causal inferences (e.g., Bertrand and Mullainathan 2000; Armstrong, Balakrishnan, and Cohen 2012). Thus, to assess whether reverse causality drives our results, we use the exogenous shock of the enactment of rightto-work (RTW) legislation. Because RTW laws prevent unions from requiring workers to join a union or pay dues to a union, these laws generally weaken labor union strength (e.g., Ellwood and Fine 1987; Zax and Ichniowski 1991). For example, Ellwood and Fine (1987) document that RTW laws significantly impair union organizing. If union strength drives conditional conservatism, then we expect a lower (higher) level of conditional conservatism in the years preceding (following) the introduction of RTW laws.

Across our sample period (1983-2006), two states, Idaho and

24) Roychowdhury and Watts (2007) suggest that asymmetric timeliness better measures conservatism when it is estimated cumulatively over longer time horizons. To examine the sensitivity of our results to different measurement horizons, we re-estimate the model (2) over 24- and 36-month periods and find that our inferences are not altered. 
Oklahoma, enacted RTW legislation in 1985 and 2001, respectively. ${ }^{25)}$ Using 629 firm-year observations from Idaho and Oklahoma, we test how the enactment of RTW laws affects conditional conservatism. To be directionally consistent with UNION, Pre-RTW is coded as 1 for Idaho and Oklahoma for sample years preceding 1985 and 2001, respectively, and zero otherwise. Given the small sample size used, this test has low power in favor of not rejecting the null. We report in Table 4 that the variable of interest, RET*NEG*Pre-RTW, has a negative and statistically significant coefficient $(-0.405$, t-stat $=-3.7)$, indicating that firms in Idaho and Oklahoma exhibit a lower level of conditional conservatism prior to the enactment of RTW laws. This result is consistent with results in Table 3 and supports the notion that union strength drives conditional conservatism. Due the low power of this test, it is not surprising that the coefficients of many of the control variables are insignificant. ${ }^{26)}$

\section{Two-stage least squares (2SLS) regression analysis}

Our second approach for dealing with potential endogeneity is to employ a two-stage least squares (2SLS) regression analysis. We use the fraction of female workers in firms' CIC industry (FEMALE) and the average worker age in CIC industry (WORKERAGE) as instrumental variables in the first stage regression because prior studies show that the levels of female workers and older workers are negatively and positively associated with unionization levels, respectively (e.g., Antos, Chandler, and Mellow 1980; Hirsch 1980), and because we have no reason to believe that FEMALE and WORKERAGE are correlated with the level of conditional accounting conservatism. We adopt the following control variables from Chen, Kacperczyk, and Ortiz-Molina (2011) for inclusion in the first stage

25) Right-to-Work Laws were adopted by each state in different years (Ellwood and Fine 1987), but mostly between mid-1940s and early 1970s. We obtain the data from the U.S. Department of Labor's website on state right-to-work laws (http:// www.dol.gov/whd/state/righttowork.htm).

26) We also execute our changes analysis by using the change in UNION. Specifically, we amend model (2) by replacing UNION with the change in unionization ( $\triangle U N I O N)$ from $\mathrm{t}-7$ to $\mathrm{t}-1$. The coefficient on our variable of interest, $R E T^{*} N E G^{*} \triangle U N I O N$, is significantly negative. This result suggests that increased levels of unionization lead to lower levels of conservatism. We recognize that our measurement period for $\triangle U N I O N$ is arbitrary, but given that unionization levels are sticky, we believe that using a longer period will provide more power for our test. Inferences are unaffected when we measure the change in unionization using different measurement horizons up to $\mathrm{t}-10$ (untabulated). 
Table 4. The effect of the enactment of right-to-work laws on changes in conditional conservatism

\begin{tabular}{|c|c|c|c|}
\hline $\mathrm{DV}=\mathrm{NI}$ & & & \\
\hline Variable & Coeff. & t-stat. & \\
\hline Intercept & 0.083 & 3.850 & $* * *$ \\
\hline$N E G$ & 0.025 & 0.240 & \\
\hline Pre-RTW & -0.025 & -0.930 & \\
\hline$B M$ & 0.021 & 0.830 & \\
\hline$L E V$ & -0.036 & -0.610 & \\
\hline SIZE & 0.000 & 1.470 & \\
\hline LIT & -0.048 & -1.870 & * \\
\hline BIDASK & -0.616 & -4.930 & $* * *$ \\
\hline$N E G^{*}$ Pre-RTW & 0.021 & 0.430 & \\
\hline$N E G^{*} B M$ & 0.060 & 0.900 & \\
\hline$N E G^{*} L E V$ & -0.045 & -0.710 & \\
\hline$N E G *$ SIZE & -0.025 & -0.330 & \\
\hline$N E G^{*} L I T$ & 0.093 & 1.750 & * \\
\hline$N E G^{*} B I D A S K$ & -0.123 & -1.480 & \\
\hline$R E T$ & -0.181 & -1.320 & \\
\hline$R E T^{*}$ Pre-RTW & 0.155 & 2.560 & * \\
\hline$R E T^{*} B M$ & 0.018 & 0.110 & \\
\hline$R E T^{*} L E V$ & -0.044 & -0.470 & \\
\hline$R E T * S I Z E$ & 0.179 & 1.280 & \\
\hline$R E T^{*} L I T$ & 0.056 & 0.740 & \\
\hline$R E T * B I D A S K$ & 0.169 & 0.850 & \\
\hline$R E T * N E G$ & 0.475 & 1.350 & \\
\hline$R E T^{*} N E G^{*}$ Pre-RTW & -0.405 & -3.700 & $* * *$ \\
\hline$R E T^{*} N E G * B M$ & 0.114 & 0.660 & \\
\hline$R E T^{*} N E G^{*} L E V$ & 0.038 & 0.290 & \\
\hline$R E T^{*} N E G^{*} S I Z E$ & -0.276 & -1.400 & \\
\hline$R E T^{*} N E G^{*} L I T$ & -0.053 & -0.380 & \\
\hline$R E T^{*} N E G * B I D A S K$ & -0.129 & -0.450 & \\
\hline $\mathrm{N}$ & \multicolumn{3}{|c|}{629} \\
\hline Sample Period & \multicolumn{3}{|c|}{ 1983-2006 } \\
\hline Standard Errors Adj. & \multicolumn{3}{|c|}{ Firms and Years } \\
\hline Adjusted $\mathrm{R}^{2}$ & \multicolumn{3}{|c|}{$25.43 \%$} \\
\hline
\end{tabular}

This table presents results from OLS regression of Basu's (1997) asymmetric timeliness framework with robust standard errors by both firm and year clusters (Petersen 2009). In this table, we use 629 observations from two states, Idaho and Oklahoma, which enacted right-to-work legislation in 1985 and 2001, respectively. Pre-RTW is coded as 1 for Idaho and Oklahoma for years preceding 1985 and 2001, respectively, and 0 otherwise. The remaining variables are identical to those presented in Table 3.

$* * *, * *, *$ indicate significance at the $0.01,0.05$, and 0.10 levels, respectively (two-sided). 
regression. LOGTA is calculated as the log of total assets. FINLEV is a leverage ratio defined as the debt to equity ratio. TOBQ is Tobin's $\mathrm{Q}$, calculated as total book value of debt plus market value of equity and liquidation value of preferred stock minus deferred taxes and investment tax credits, divided by the book value of assets. CFRISK is the standard deviation of $R O A$ for the previous 16 quarters. $R O A$ is return on assets and PROFIT is measured as operating income divided by total assets. INTANG is the ratio of intangible assets to total assets. TOTPAYOUT is the sum of dividend payout and repurchases, scaled by total assets. SALES/ASSETS is measured as the ratio of the firm's sales to its total assets.

Because the Basu (1997) measure of conservatism does not lend itself to the 2SLS framework (i.e., the dependent variable in the Basu framework is not a measure of conservatism), we use CSCORE (Khan and Watts 2009) as our measure of conservatism in the second stage regression. CSCORE is a measure of the propensity for conditional conservatism and is estimated following Khan and Watts (2009). We first estimate the following Basu (1997) model for pooled cross-sectional data ${ }^{27)}$ :

$$
\begin{aligned}
N I_{i, t} & =\eta_{1}+\eta_{2} N E G_{i, t}+R E T_{i, t}\left(\mu_{1}+\mu_{2} \operatorname{Size}_{i, t}+\mu_{3} M / B_{i, t}+\mu_{4} \operatorname{Lev}_{i, t}\right) \\
& +N E G_{i, t}{ }^{*} R E T_{i, t}\left(\lambda_{1}+\lambda_{2} \operatorname{Size}_{i, t}+\lambda_{3} M / B_{i, t}+\lambda_{4} \operatorname{Lev}_{i, t}\right) \\
& +\left(\delta_{1} \operatorname{Size}_{i, t}+\delta_{2} M / B_{i, t}+\delta_{3} \operatorname{Lev}_{i, t}+\delta_{4} N E G_{i, t}{ }^{*} \operatorname{Size}_{i, t}\right. \\
& \left.+\delta_{5} N E G_{i, t}{ }^{*} M / B_{i, t}+\delta_{6} N E G_{i, t}{ }^{*} \operatorname{Lev}_{i, t}\right)+\varepsilon_{i, t}
\end{aligned}
$$

We then combine the estimated coefficients from model (3) and the values for firm-specific size, market-to-book, and leverage to calculate CSCORE in the following model:

$$
\text { CSCORE }=\lambda_{1, t}+\lambda_{2, t} \operatorname{Size}_{i, t}+\lambda_{3, t} M / B_{i, t}+\lambda_{4, t} \operatorname{Lev}_{i, t}
$$

27) In estimating the values of CSCORE, we calculate the regression variables as defined in Khan and Watts (2009). The definitions of some variables are therefore slightly different from those used in our estimation of Equation (2). Specifically, in Equations (5) and (6), NI is measured as earnings before extraordinary items deflated by lagged market value of equity; RET represents CRSP buy-and-hold returns cumulated over the twelve-month window ending three months after fiscal year end; $M / B$, the market-to-book ratio, is used instead of the book-to-market ratio; Lev, the leverage ratio, is calculated as the sum of the long-term debt and current liabilities, scaled by lagged market value of equity; Size is the natural log of market value of equity. NEG is an indicator variable coded as 1 if RET is less than zero, and 0 otherwise. 
High CSCORE indicates a high degree of conditional conservatism.

In Panel A of Table 5, we report the results of estimating the first-stage model. We document a negative and significant coefficient on FEMALE and a positive and significant coefficient on WORKERAGE ${ }^{28)}$ Results on other variables are generally consistent with prior literature. In Panel B, we report results for the secondstage regression. Note that we employ a fixed effects model in Table 5, following Ball, Kothari, and Nikolaev (2013), to address a criticism by Patatoukas and Thomas (2011) regarding the asymmetric timeliness measure. Therefore, LIT, which is firm-invariant in our sample, is not estimated in Panel B. Note that we substitute LOGTA (log of total assets), SGROWTH (sales growth from $t-1$ to $t$ ), and AGE (age of the firm - older firms are more likely to have more debt than younger firms) for $S I Z E, M B$, and $L E V$, respectively, in the second stage regression because CSCORE is a linear combination of SIZE, $M B$, and $L E V .{ }^{29)}$ Results in Panel $\mathrm{B}$ show a negative relation between union strength and conservatism (coefficient $=-1.047, t=-7.19$ ), even after controlling for the endogenous nature of UNION in the first stage regression. The coefficients on LOGTA and SGROWTH are consistent with predictions. The coefficient of $A G E$ is insignificant, while the coefficient on BIDASK is directionally inconsistent with our prediction.

Taken together, results based on the enactment of Right-to-Work (RTW) Laws and the 2SLS analysis support the conclusion that endogeneity does not likely affect inferences for our main results in Table 3.

\section{Unions and the Likelihood of Layoffs}

In this section, we provide corroborating evidence consistent with the economic mechanism under which the negative relation between union strength and conditional conservatism could exist. In our hypothesis development, we argue that one plausible negative link between unions and conservatism is unions' deterrence of the likelihood of layoffs. Union tends to reduce layoffs of employees

28) When we check the relevance of our instrumental variables using a simple model (i.e., UNION $=f(F E M A L E$, WORKERAGE $)$ in the first stage), the Hansen $\mathrm{J}$ statistic is $0.902869(\mathrm{p}=0.3420)$, which implies that we cannot reject the null that the over-identification restrictions are valid.

29) We thank Mozaffar Khan for suggesting these substitutions. 


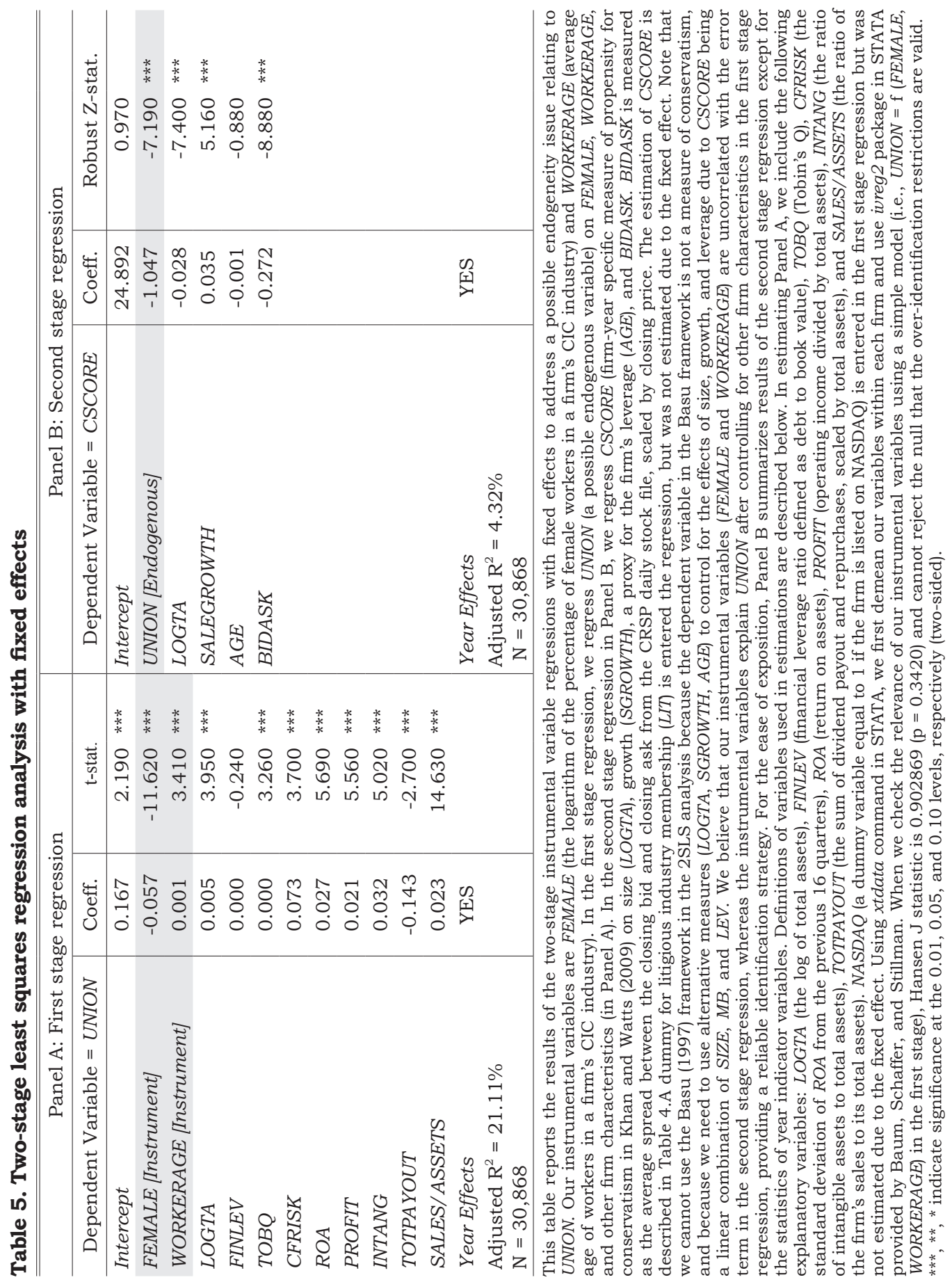


by discouraging managers from timely abandoning negative NPV projects, similar to the findings of Antanassov and Kim (2009). Thus, we examine how the likelihood of layoffs is related to union strength below. We predict a negative relation between union strength and the likelihood of layoffs. To test this relation, we employ the following model which is based on Antanassov and Kim (2009).

$$
\begin{aligned}
f(L A Y O F F) & =\theta_{0}+\theta_{1} \text { UNION }+\theta_{2} L E V+\theta_{3} O W N+\theta_{4} M G M T O W N \\
& +\theta_{5} \text { SIZE }+\theta_{6} \text { PERFORMANCE }+ \text { Industry dummies } \\
& + \text { Year dummies }+\varepsilon
\end{aligned}
$$

$L A Y O F F$, is a dichotomous variable coded as one for a firm year with a decrease of $20 \%$ or greater in the number of employees, and zero otherwise. ${ }^{30)} O W N$ is the percentage of shares owned by the three largest shareholders holding 5\% or more of the company's shares outstanding. MGMTOWN is an indicator variable coded as one if one or more officers own at least $5 \%$ of the company's shares outstanding, and zero otherwise. OWN and MGMTOWN are measured using data from the Compustat Blockholder database. SIZE is the natural logarithm of sales. PERFORMANCE is measured as operating income before depreciation scaled by beginning-of- year total assets. Pinnuck and Lillis (2007) suggest that accounting losses are more likely to lead to layoffs. UNION and LEV are as defined in Table 2. The sample consists of 4,273 firm-year observations for years 1995-2001 due to the availability of blockholder data.

Table 6 presents the results of logistic regressions examining the effect of union strength on the likelihood of layoffs. Consistent with our prediction, the coefficient on $U N I O N$ is significantly negative ( $\mathrm{p}$-value $=<.001$, one-tailed), suggesting that the extent of union strength reduces the likelihood of layoffs.

30) Following Antanassov and Kim (2009), we use $20 \%$ as the cutoff point in characterizing the event of layoffs. Inferences are unaffected when we use $10 \%$ or $15 \%$ as the threshold. 
Table 6. Impact of unions on the likelihood of massive layoffs

\begin{tabular}{l|c|c}
\hline \hline DV: Pr(LAYOFF $=1)$ & Coeff. & Wald $\chi^{2}$ \\
\hline Variable & -10.687 & $170.194^{* * *}$ \\
Intercept & -11.234 & $27.004^{* * *}$ \\
UNION & -1.402 & $12.137 * * *$ \\
LEV & -0.455 & 0.570 \\
OWN & -0.538 & $4.253 * *$ \\
MGMTOWN & -0.158 & $4.761^{* *}$ \\
SIZE & -7.033 & $55.618 * * *$ \\
PERFORMANCE & \multicolumn{2}{|c}{ YES } \\
\hline Year \& Industry Effects & \multicolumn{2}{|c}{ 1995-2001 } \\
N & \multicolumn{2}{|c}{ Firms } \\
Sample Period & $21.03 \%$ \\
Standard Errors Adj. & \multicolumn{2}{|c}{ Pseudo R ${ }^{2}$} \\
\hline
\end{tabular}

This table presents results from the logistic regression of the existence of layoffs on the level of unionization (UNION). The dependent variable, LAYOFF, is a dichotomous variable coded as 1 when a decrease in the number of employees is greater than or equal to $20 \%$, and 0 otherwise. OWN is the percentage of shares owned by the three largest shareholders holding $5 \%$ or more of the company's shares outstanding. MGMTOWN is an indicator variable coded as 1 if one or more officers own at least $5 \%$ of the company's shares outstanding, and 0 otherwise. OWN and MGMTOWN are measured using data from the Compustat Blockholder database. SIZE is the natural logarithm of sales (Compustat \#12). PERFORMANCE is measured as operating income before depreciation (Compustat \#13) scaled by beginning of year total assets (Compustat \#6). UNION and LEV are as defined in Table 2. We report Wald Chi-squared statistics based on standard errors clustered by firms. Year and industry indicators (based on 2-digit SIC code) are included in the model. The sample size has been reduced to 4,273 $(4,080)$ firm-year observations in Panel A (Panel B) for years 1995-2001 due to the availability of blockholder data. $* * *, * *, *$ indicate significance at the $0.01,0.05$, and 0.10 levels, respectively (one-sided). 


\section{SENSITIVITY TESTS AND DISCUSSION}

We performed the following series of untabulated robustness tests.

\section{Alternative Measures of Labor Union Strength}

We consider three other labor strength measures: (1) an indicator variable for the occurrence of labor strike, (2) a blue state vs. red state indicator variable, and (3) an indicator variable based on whether a firm has a defined benefit plan.

The first alternative union strength measure is based on whether a strike has occurred. Strikes reflect enhanced union strength because the occurrence of a strike suggests an increased likelihood of future strikes (e.g., Dinardo and Hallock 2002; Choi, Plehn-Dujowich, and Zhang 2012). For example, Dinardo and Hallock (2002) interpret the negative stock market reaction to strike announcements as an indication of stronger unions. STRIKE is coded as 1 for firm-year observations that include a labor strike during the years 1990 to 2006 and 0 otherwise. ${ }^{31)}$ Our second alternative measure is based on implicit assumptions that firms located in blue states are those with more Democratic politicians, who unions tend to support. Our third measure is based on the argument that firms with defined benefit plans tend to be large industrial firms that are more likely to have better established unions. Firms that are in blue states and that have defined benefit plans are therefore more likely to be labor-friendly, yielding stronger labor unions. We re-estimate our main regression (2) using these three alternative measures and find that firms experiencing a strike, firms in blue states, and firms with defined benefit plans exhibit a lower level of conditional

31) We obtain the strike data from BNA PLUS work stoppage reports for labor strikes, which list strikes by location of the establishment affected by the strike and provide information such as the name of the employer, beginning and ending dates of the strike, 2-digit SIC code, number of employees, identity of the union, and additional details if available. Because the location information pertains to the firm affected by the work stoppage rather than the location of the headquarters, we can only identify a company experiencing a strike based on its name and industry membership when extracting financial information from Compustat for further analyses. The manual matching process based on company names and industry membership produces 134 unique companies from 31 industries (based on 2-digit SIC code) that experience labor strikes at one point during the years 1990-2006. 
conservatism than firms without a strike, firms in red states, and non-defined benefit plan firms, respectively. ${ }^{32)}$ For example, when STRIKE is used, the coefficient on RET*NEG*STRIKE is negative and significant $(-0.098$, t-stat $=-1.86)$, indicating that firm-years which contain strikes exhibit a lower level of conditional conservatism compared to firm-years without strikes.

Finally, to address a potential measurement error arising from firms with multiple segments, we use segment sales data and segment industry information to generate an industry-weighted UNION measure, SEG_UNION. We replace UNION in Table 3 with $S E G \_U N I O N$ and estimate the model, finding that inferences are unaffected. Specifically, the coefficient on $R E T^{*} N E G^{*} S E G_{-}$UNION is -0.13 (t-value $=-4.07)$.

\section{Industry Level Analysis}

We also conduct tests using industry-level unionization data. In this estimation, we adjust standard errors for both industry and year. Similar to Ball, Bushman, and Vasvari (2008), we run pooled Basu (1997) regressions (i.e., a full model without any of the UNIONrelated variables) with firm-level data within each CIC industry and year, following the literature in labor economics (Chen, Kacperczyk, and Ortiz-Molina 2011). We obtain the conservatism estimates (i.e., RET*NEG coefficients) and regress them on CIC industry-level unionization rates. We find that the coefficient on UNION is negative and significant (coeff. $=-0.037$; $\mathrm{t}$-value $=-2.24$ ), consistent with our main findings.

\section{Other Sensitivity Analyses}

- LaFond and Roychowdhury (2008) show that managerial ownership is negatively related to conditional conservatism. We measure CEO ownership as the annual decile ranking of CEO share ownership for the sub-sample covered by the ExecuComp database for the

32) We also create a dichotomous variable, $N O N-R T W$ (i.e., states with forced union membership), which is coded as 1 for sample years during which a state does not have RTW laws in place and 0 otherwise. States with right-to-work laws are AL, AZ, AR, FL, GA, ID, IA, KS, LA, MS, NE, NV, NC, ND, OK, SC, SD, TN, TX, UT, VA, and WY. Note that NON-RTW is directionally consistent with UNION. Results with NON-RTW are also similar to those with UNION. 
years 1992-2006 and control for it in our main regressions. The inclusion of CEO ownership does not alter the tenor of reported results.

- To address the relation between conditional and unconditional conservatism, as in Beaver and Ryan (2005), we re-estimate our main results after including C-Index, Penman and Zhang's (2002) measure of unconditional conservatism, and find that main results hold.

- The level of conditional conservatism has increased over our sample period (Basu 1997; Holthausen and Watts 2001; Ryan and Zarowin 2003), whereas private sector unionization has decreased over time. It is therefore possible that our results obtain due to a spurious regression bias (e.g., Ferson, Sarkissian, and Simin 2003). To rule out this possibility, we re-estimate our main model after including TIME, a dummy variable that equals 1 for the baseline year of 1983, with a one unit increase in its value for each additional year of our sample period to control for the increasing time trend in conditional conservatism. Our main inferences are unaffected after controlling for TIME, suggesting that our reported results are not due to the time trend in conservatism.

\section{Discussion}

Our study is related to a contemporaneous working paper by Leung, Li, and Rui (2009). Contrary to our findings, they document the positive relation between labor union strength and conditional conservatism. There are important differences between our studies that can explain this difference. First, Leung, Li, and Rui (2009) run the Basu (1997) model for two-year windows around initial election (i.e., two years pre- and post-election) only with 200 firms. ${ }^{33)}$ In our setting, by contrast, unions are plausibly more firmly established and thus likely in a stronger position to use the threat of strikes. Second, their measurements of conservatism and unionization differ from ours. The conservatism measures used by Leung, Li, and Rui (2009) are constructed using the coefficients generated from the

33) Note that Leung, Li, and Rui (2009) report a negative and significant coefficient on NEG*RET in their Table 9, implying that firms in their sample are less timely in reporting losses compared to gains. This result is opposite to our result and what the Basu (1997) asymmetric timeliness model predicts, thereby highlighting the stark difference between our samples. 
estimation of simple Basu (1997) regressions for each industryyear using 10-year rolling windows. These conservatism measures are then used as dependent variables in subsequent regressions on the union coverage ratio and control variables derived from Francis, LaFond, Olsson, and Schipper (2004). Except for firm size, their model does not include conservatism predictors of leverage, book-to-market, or litigation. When we perform a similar industrylevel analysis by obtaining the coefficients from an expanded Basu (1997) model (i.e., a model with size, book-to-market, leverage, and litigation controls), we find a negative relation between conservatism and an industry-level union measure. Hui, Klasa, and Yeung (2012) conduct a similar test and show that the sign of the coefficient on UNION is negative, consistent with our findings. Another difference between two studies is that our test period spans the years 19832006, while Leung, Li, and Rui's (2009) test period spans the years 1990-2002. To determine whether this contributes to the different results, we re-estimate our main results using the years 1990-2002 and obtain results similar to those we report (untabulated). Thus, the difference in test periods does not likely drive the difference in results between our study and Leung, Li, and Rui (2009). The different bases used for the estimation of asymmetric timeliness of earnings and union power make a comparison between our studies problematic.

\section{SUMMARY AND CONCLUSION}

In this study, we use Basu's (1997) asymmetric timeliness framework to examine the relation between labor union strength and conditional conservatism. We posit that labor unions' demand for conservatism is not one directional. Since conditional conservatism, timely loss recognition, can lower unions' perception of employer's ability to pay their wages and salaries and increase the likelihood of managers' layoff decision, unions would likely demand less conditional conservatism. In this case, we predict the negative relation between conditional conservatism and union strength. When unions desire less conditional conservatism, they can enforce their demand by restraining managers' incentive to supply conservatism through the threat of strikes. However, unions also have a greater demand for downside information about the firm's prospects to 
protect their long-term job securities. If unions demand more conservatism, managers will satisfy the demand by supplying more conservatism to increase managers' bargaining advantage, thus the relation between union strength and conditional conservatism can also be positive. To summarize, there are competing demand and supply forces that leave the relation between union strength and conditional conservatism an empirical question.

Using a large sample over the period 1983-2006, we find that firms with more powerful unions exhibit less conditional conservatism. This result obtains even after controlling for known sources of conservatism, including bid-ask spread, the book-to-market ratio, firm size, leverage, and litigation risk. We further find that results are economically significant. Our results are robust to tests for reverse causality and correlated omitted variables, as well as to a battery of other sensitivity tests. We further explore what drives the negative relation between unions and conservatism by examining employee layoffs. We document that the likelihood of layoffs is negatively (positively) associated with union strength (conservatism).

We contribute to the literature on accounting conservatism by demonstrating that an important stakeholder, namely labor unions, can affect the practice of accounting conservatism. Recent work by Hui, Klasa, and Yeung (2012) demonstrates a positive relation between strong suppliers, also a key stakeholder, and conditional conservatism. Our findings show that labor unions, with a payoff function similar to that of suppliers, can have a different effect on conditional conservatism due to their unique incentives to discourage managers' layoff decisions.

A few caveats and research avenues are in order. First, because we utilize the data from the US, we do not employ a direct measure of a firm-level union strength (an actual firm-level unionization rate which is available in Korea) in this study. This is one limitation of our study and future studies can utilize Korean data for a direct measure. Second, although we demonstrate the relation between labor union strength and conditional conservatism, evidence on the source of the relation is not fully presented. Future studies can further identify how the relative bargaining power between creditors and employees would vary with the degree of financial distress. Finally, our paper explores how labor union strength is negatively related to the probability of massive layoffs in attempt to corroborate the main findings. Given this evidence, future studies can further 
provide evidence on whether labor union strength is related to the likelihood and level of write-downs, restructuring charges or negative special items charges.

\section{REFERENCES}

Abraham, K. G., and J. L. Medoff (1984), "Length of service and layoffs in union and nonunion work groups," Industrial Labor Relations Review, 38, 87-97.

Ahmed, A. S., B. K. Billings, R. M. Morton, and M. Harris-Stanford (2002), "The role of accounting conservatism in mitigating bondholdershareholder conflicts over dividend policy and in reducing debt costs," The Accounting Review, 77(4), 867-890.

Ahmed, A., and S. Duellman (2007), "Accounting conservatism and board of director characteristics: An empirical analysis," Journal of Accounting and Economics, 43(2-3), 411-437.

Antanassov, J., and E. H. Kim (2009), "Labor and corporate governance: International evidence from restructuring decisions," The Journal of Finance, 64(1), 341-374.

Antos, J. R., M. Chandler, and W. Mellow (1980), "Sex differences in union membership," Industrial and Labor Relations Review, 33(2), 162-169.

Armstrong, C. S., K. Balakrishnan, and D. Cohen (2012), "Corporate governance and the information environment: Evidence from state antitakeover laws," Journal of Accounting and Economics, 53(1-2), 185204.

Ball, R. (2001), "Infrastructure Requirements for an economically efficient system of public financial reporting and disclosure," Brookings-Wharton Papers on Financial Services, 127-169.

Ball, R., R. M. Bushman, and F. P. Vasvari (2008), "The debt-contracting value of accounting information and loan syndicate structure," Journal of Accounting Research, 46(2), 247-287.

Ball, R., S. Kothari, and V. Nikolaev (2013), "On estimating conditional conservatism," The Accounting Review, 88(3), 755-787.

Ball, R., A. Robin, and G. Sadka (2008), "Is financial reporting shaped by equity markets or by debt markets? An international study of timeliness and conservatism," Review of Accounting Studies, 13(3), 168205.

Ball, R., and L. Shivakumar (2005), "Earnings quality in UK private firms: comparative loss recognition timeliness," Journal of Accounting and Economics, 39(1), 83-128.

Basu, S. (1997), "The conservatism principle and the asymmetric timeliness 
of earnings," Journal of Accounting and Economics, 24(1), 3-37.

Beatty, A., J. Weber, and J. Yu (2008), "Conservatism and debt," Journal of Accounting and Economics, 45(2-3), 154-174.

Beaver, W. H., and S. G. Ryan (2005), "Conditional and unconditional conservatism: Concepts and modeling," Review of Accounting Studies, 10(2-3), 269-309.

Bertrand, M., and S. Mullainathan (2000), "Agents with and without Principals," American Economic Review, 90(2), 203-208.

Bertrand, M., and S. Mullainathan (2003), "Enjoying the quiet life? Corporate governance and managerial preferences," Journal of Political Economy, 111(5), 1043-1075.

Bova, F. (2013), "Labor unions and management's incentive to signal a negative outlook," Contemporary Accounting Research, 30(1), 14-41.

Bowen, R. M., L. DuCharme, and D. Shores (1995), "Stakeholders' implicit claims and accounting method choice," Journal of Accounting and Economics, 20(3), 255-295.

Chen, H., M. Kacperczyk, and H. Ortiz-Molina (2011), "Labor unions, operating flexibility, and the cost of equity," Journal of Financial and Quantitative Analysis, 46(1), 25-58.

Chen, H., M. Kacperczyk, and H. Ortiz-Molina (2012), "Do non-financial stakeholders affect agency costs of debt? Evidence from unionized workers," Review of Finance, 16(2), 347-383.

Choi, J. J., J. M. Plehn-Dujowich, and X. T. Zhang (2012), Labor as a monitor of the CEO: Evidence of power play in outsourcing, Working Paper, Temple University.

Cornell, B., and A. Shapiro (1987), "Corporate stakeholders and corporate finance," Financial Management, 16(1), 5-14.

Craft, J. A. (1981), "Information disclosure and the role of the accountant in collective bargaining," Accounting, Organizations and Society, 6(1), 97107.

Cullinan, C. P., and J. A. Knoblett (1994), "Unionization and accounting policy choices: An empirical examination," Journal of Accounting and Public Policy, 13(1), 49-78.

Darlington, R. B. (1968), "Multiple regression in psychological research and practice," Psychological Bulletin, 69(3), 161-182.

DeAngelo, H., and L. DeAngelo (1991), "Union negotiations and corporate policy: A study of labor concessions in the domestic steel industry during the 1980s," Journal of Financial Economics, 30(1), 3-43.

Dinardo, J., and K. F. Hallock (2002), "When unions "Mattered": The impact of strikes on financial markets, 1925-1937," Industrial and Labor Relations Review, 55, 219-233.

D'Souza. J., J. Jacob, and K. Ramesh (2001), "The use of accounting flexibility to reduce labor renegotiation costs and manage earnings," 
Journal of Accounting and Economics, 30(2), 187-208.

Ellwood, D. T., and G. Fine (1987), "The impact of right-to-work laws on union organizing," Journal of Political Economy, 95, 250-273.

Faleye, O., V. Mehrotra, and R. Morck (2006), "When labor has a voice in corporate governance," Journal of Financial and Quantitative Analysis, 41(3), 489-510.

Fama, E. F., and J. D. MacBeth (1973), "Risk, return and equilibrium Empirical tests," The Journal of Political Economy, 81(3), 607-636.

Ferson, W. E., S. Sarkissian, and T. Simin (2003), "Spurious regressions in Financial Economics?” The Journal of Finance, 58(4), 1393-1414.

Flanagan, R. (2005). "Has management strangled U.S. unions?" Journal of Labor Research, 26, 33-63.

Foley, B. J. and K. T. Maunders (1977), Accounting information disclosure and collective bargaining, The Macmillan Press Ltd, London, U.K.

Francis, J., R. LaFond, F. Olsson, and K. Schipper (2004), "Costs of equity and earnings attributes," The Accounting Review, 79(4), 967-1010.

Francis, J., and X. Martin (2009), "Acquisition profitability and timely loss recognition," Journal of Accounting and Economics, 49(1-2), 161-178.

Frost, A. (2000), "Explaining variation in workplace restructuring: The role of local union capabilities," Industrial and Labor Relations Review, 53, 559-578.

Giroud, X., and H. M. Mueller (2011), "Corporate governance, product market competition, and equity prices," The Journal of Finance, 66(2), 563-600.

Givoly, D., C. Hayn, and A. Natarajan (2007), "Measuring reporting conservatism," The Accounting Review, 82(1), 65-106.

Hilary, G. (2006), "Organized labor and information asymmetry in financial markets," Review of Accounting Studies, 11(4), 525-548.

Hirsch, B. T. (1980), "The determinants of unionization: An analysis of inter area differences," Industrial and Labor Relations Review, 33(2), 147161.

Hirsch, B. T. (1991), Labor unions and the economic performance of firms, W. E. Upjohn Institute for Employment Research, Kalamazoo, MI.

Hirsch, B. T., and D. A. Macpherson (2003), "Union membership and coverage database from the Current Population Survey: Note," Industrial and Labor Relations Review, 56(2), 349-54.

Hirsch, B. T. (2004), "What do unions do for economic performance?" Journal of Labor Research, 25, 415-456.

Holthausen, R. W., and R. Watts (2001), "The Relevance of the value relevance literature for financial accounting standard setting," Journal of Accounting and Economics, 31(1-3), 3-76.

Hui, K. W., S. Klasa, and E. Yeung (2012), "Corporate suppliers and customers and accounting conservatism," Journal of Accounting and 
Economics, 53(1-2), 115-135.

Katz, H. (1993), "The decentralization of collective bargaining: A literature review and comparative analysis," Industrial and Labor Relations Review, 47, 3-22.

Khan, M., and R. L. Watts (2009), "Estimation and empirical properties of a firm-year measure of conservatism," Journal of Accounting and Economics, 48(2-3), 132-150.

Kim, I., and D. R. Skinner (2012), "Measuring securities litigation risk," Journal of Accounting and Economics, 53(1-2), 290-310.

Klasa, S., W. F. Maxwell, and H. Ortiz-Molina (2009), "The strategic use of corporate cash holdings in collective bargaining with labor unions," Journal of Financial Economics, 92(3), 421-442.

LaFond, R., and S. Roychowdhury (2008), "Managerial ownership and accounting conservatism," Journal of Accounting Research, 46(1), 101135.

LaFond, R., and R. L. Watts (2008), "The information role of conservatism," The Accounting Review, 83(2), 447-478.

Lawrence, A., R. G. Sloan, and Y. Sun (2013), Mandatorily conservative accounting: Evidence and implications, Working Paper, University of California at Berkeley and Boston University.

Leung, W. S. C., O. Z. Li, and O. M. Rui (2009), Labor union and accounting conservatism, Working Paper, The Chinese University of Hong Kong, National University of Singapore, and China Europe International Business School.

Liberty, S. E., and J. L. Zimmerman (1986), "Labor union contract negotiations and accounting choices," The Accounting Review, 61(4), 692-712.

Maksimovic, V., and S. Titman (1991), "Financial policy and reputation for product quality," Review of Financial Studies, 4(1), 175-200.

Mautz, R. D., and F. M. Richardson (1992), "Employer financial information and wage bargaining: Issues and evidence," Labor Studies Journal, 17(3), 35-52.

Modigliani, F., and M. Miller (1958), "The cost of capital, corporation finance and the theory of investment," American Economic Review, 48(3), 261297.

Palmer, J. R. (1977), The use of accounting information in labor negotiations, National Association Accountants, New York, NY.

Patatoukas, P. N., and J. K. Thomas (2011), "More evidence of bias in the differential timeliness measure of conditional conservatism," The Accounting Review, 86(5), 1765-1793.

Penman, S. H., and X. Zhang (2002), "Accounting conservatism, the quality of earnings, and stock returns," The Accounting Review, 77(2), 237-264.

Petersen, M. (2009), "Estimating standard errors in finance panel data sets: 
Comparing approaches," Review of Financial Studies, 22(1), 435-480.

Pinnuck, M., and A. Lillis (2007), "Profits versus losses: Does reporting an accounting loss act as a heuristic trigger to exercise the abandonment option and divest employees?" The Accounting Review, 82(4), 10311053.

Roychowdhury, S., and R. Watts (2007), "Asymmetric timeliness of earnings, market-to-book and conservatism in financial reporting," Journal of Accounting and Economics, 44(1-2), 2-31.

Ryan, S. G., and P. Zarowin (2003), "Why has the contemporaneous linear returns-earnings relation declined?” The Accounting Review, 78(2), 523553.

Thompson, S. (2011), "Simple formulas for standard errors that cluster by both firm and time," Journal of Financial Economics, 99(1), 1-10.

Verdi, R. S. (2006), Financial reporting quality and investment efficiency, Working Paper, MIT.

Visser, J. (2006), "Union membership statistics in 24 countries," Monthly Labor Review, 129, 38-49.

Watts, R. L. (1993), A proposal for research on conservatism, Working Paper, University of Rochester.

Watts, R. L. (2003a), "Conservatism in accounting Part I: Explanations and implications," Accounting Horizons, 17(3), 207-221.

Watts, R. L. (2003b), "Conservatism in accounting Part II: Evidence and research opportunities," Accounting Horizons, 17(4), 287-301.

Wittenberg-Moerman, R. (2008), "The role of information asymmetry and financial reporting quality in debt trading: Evidence from the secondary loan market," Journal of Accounting and Economics, 46(2-3), 240-260.

Yamaji, H. (1986). "Collective bargaining and accounting disclosure: An inquiry into the changes in accounting policy," International Journal of Accounting Education and Research, 22(1), 11-23.

Zax, J. S., and C. Ichnioski (1991), "Excludability and the effects of free riders: Right-to-Work laws and local public sector unionization," Public Finance Quarterly, 19, 293-315.

Zhang, J. (2008), "The contracting benefits of accounting conservatism to lenders and borrowers," Journal of Accounting and Economics, 45(1), 27-54. 
